\title{
Results of advanced core decompression in patients with osteonecrosis of the femoral head depending on age and sex-a prospective cohort study
}

\author{
Sebastian Serong ${ }^{1 *}$, Marcel Haversath², ${ }^{2}$ jark Tassemeier ${ }^{2}$, Florian Dittrich ${ }^{1}$ and Stefan Landgraeber ${ }^{1}$
}

\begin{abstract}
Background: Core decompression is a common surgical technique to treat osteonecrosis of the femoral head. The aim of this study is to evaluate the effect of the parameters "age" and "sex" on the outcome of this type of treatment.

Methods: A prospective cohort study was performed. Eighty-six osteonecrotic hips with a mean follow-up of 32.5 months ( \pm 24.8) after advanced core decompression were analysed regarding age- and sex-dependent treatment failure.

Additionally, the modified Harris Hip Score and Numeric Rating Scale were compared regarding the parameters age and sex.

Results: The mean hip survival of the male participants was 51.3 months (39.4\% treatment failure), whereas females presented a longer, thus not significant, mean survival of 61.4 months (30\% therapy failure; $p=0.48$ ). The further evaluation revealed significantly better survival in the patients aged $<40$ years (mean survival 66.09 months, $16 \%$ treatment failure) in comparison to those aged $\geq 40$ years (mean survival 50.14 months, $46 \%$ therapy failure; $p=0.03$ ). The modified Harris Hip Score and Numeric Rating Scale results of patients whose treatment did not fail during the study period were similar, irrespective of the patient's sex or age.

Conclusions: The study shows that the number of therapy failures is significantly higher in older patients, with 40 years of age marking the borderline. Patients' sex does not seem to affect the outcome of treatment, and postoperative clinical scores appear to be identical with individuals not affected by therapy failure. Since age and sex are unalterable parameters, the study helps to provide valuable predictions regarding the chances of long-term hip survival after treatment of osteonecrosis.
\end{abstract}

Keywords: Osteonecrosis, Hip, Core decompression, Age, Sex

\section{Background}

Osteonecrosis of the femoral head (ONFH) is a pathological condition of the hip joint characterized by impaired blood supply which induces progressing structural instability. Missed or delayed treatment regularly results in collapse of the femoral head with arthroplasty being the only

\footnotetext{
* Correspondence: sebastian.serong@uks.eu

'Department of Orthopaedics \& Orthopaedic Surgery, Saarland University, Kirrberger Strasse 100, 66421 Homburg, Germany

Full list of author information is available at the end of the article
}

remaining treatment option $[1,2]$. It is supposed that ONFH is based on a multifactorial genesis of which several risk factors such as corticosteroid treatment, coagulopathies and heavy alcohol and nicotine consumption have been identified $[3,4]$. The average prevalence is estimated to be 29 out of 100,000 each year with a peak in age distribution between 30 and 50 years. A further typical finding is the predominant occurrence of ONFH in the male sex $[5,6]$.

As ONFH harbours the severe risk of irreversible damage to the affected hip, it is essential that treatment should

C C The Author(s). 2020 Open Access This article is licensed under a Creative Commons Attribution 4.0 International License, which permits use, sharing, adaptation, distribution and reproduction in any medium or format, as long as you give appropriate credit to the original author(s) and the source, provide a link to the Creative Commons licence, and indicate if changes were made. The images or other third party material in this article are included in the article's Creative Commons licence, unless indicated otherwise in a credit line to the material. If material is not included in the article's Creative Commons licence and your intended use is not permitted by statutory regulation or exceeds the permitted use, you will need to obtain permission directly from the copyright holder. To view a copy of this licence, visit http://creativecommons.org/licenses/by/4.0/. The Creative Commons Public Domain Dedication waiver (http://creativecommons.org/publicdomain/zero/1.0/) applies to the data made available in this article, unless otherwise stated in a credit line to the data. 
be commenced as soon as possible. Non-surgical options have been described for treatment of early-stage ONFH that is often characterized by diffuse bone marrow oedema [7-9]. In that context iloprost, enoxaparin and bisphosphonate treatment have been reported [10-12]. Moreover, recent studies showed extracorporeal shock wave therapy to be a further promising approach in the management of early-stage ONFH [13-15].

However, to the present day, surgical procedures still are the therapy of choice in most cases, especially when necrotic zones have begun to demarcate $[3,16]$. Several techniques have been published with core decompression and its variations being one of the most frequently performed procedures. All types of core decompression aim at pain reduction and long-term preservation of the femoral head provided that it has not yet collapsed [3, 17]. Although differences in the rate of hip survival have been reported depending on the type of procedure performed, there are further factors that distinctly limit therapy success. Treatment of advanced ONFH stages as described in the ARCO and Steinberg classifications is more likely to fail than treatment of early ones $[3,18-$ 20]. Lesion size also seems to have a significant effect on outcome, with larger lesions often resulting in joint-line collapse despite surgery [21]. Concomitant pathologies of the hip joint such as the femoroacetabular impingement syndrome seem to reduce the rate of therapy success in ONFH even further [22]. Furthermore, therapy is also more likely to be jeopardised if known risk factors such as ongoing corticosteroid treatment or addictive alcohol consumption cannot be eliminated.

As for the parameters "age" and "sex", their influence on ONFH therapy outcome has so far not been sufficiently evaluated. Shimizu et al. were able to show that alcohol-induced ONFH was more often triggered in male rats than in females and thereby supposed the presence of unknown sex-based factors for its predominant occurrence in men [23]. However, they did not provide a prognosis concerning therapy outcome depending on sex. The same applies for the parameter "age". We know the age distribution for the occurrence of ONFH but nothing about its influence on therapy success. This study therefore aims to present the age- and sexdependent outcome of ONFH therapy through advanced core decompression.

\section{Methods}

A prospective, non-randomized design was chosen (level II-prospective cohort study). The study was approved by the institutional review board of the University of Duisburg-Essen, and informed consent was obtained from all participants. Conventional $\mathrm{x}$-ray and magnetic resonance imaging were used to diagnose ONFH. In order to avoid a stage-dependent outcome bias, only patients with ARCO and Steinberg stage 2 lesions were included [20, 24]. All patients underwent detailed preoperative physical examination and were followed up regularly at the Department of Orthopaedics and Traumatology of the University Hospital Essen. The recorded parameters included the modified Harris Hip Score (mHHS) for evaluation of hip function and the numeric rating scale (NRS) for pain quantification [25, 26]. ONFH was treated solely by advanced core decompression $(\mathrm{ACD})$ and its modified version $(\mathrm{mACD})$ between the years 2011 and 2016 as described by Landgraeber et al. $[17,27]$. Both methods are characterized by fluoroscopic-guided drilling into the defect zone and removal of the necrotic tissue using an expandable reamer. Whereas intraosseous defects were filled solely with synthetic bone substitute composed of calcium sulfate $\left(\mathrm{CaSO}_{4}\right) /$ calcium phosphate $\left(\mathrm{CaPO}_{4}\right)$ in conventional ACD, a mixture of autologous cancellous bone from the femoral neck and the same synthetic bone substitute was used in cases of $\mathrm{mACD}$.

The study collective included 71 patients with ONFH resulting in a total number of 86 affected hips due to 15 cases of bilateral occurrence. The follow-up period was termed for 2 years with postoperative assessment points set at 6 weeks, 6 months, 12 months and 24 months. As numerous patients continued to regularly present themselves, a longer overall follow-up period of 32.5 months was calculated. The primary objective of the study was to evaluate the long-term results of ONFH treatment by ACD considering the parameters "age" and "sex" in particular. In order to assess the treatment outcome, subgroups on the basis of these two specific parameters were formed. Detailed baseline characteristics of the entire study collective as well as the created subgroups are presented in Table 1 and Table 2.

We proposed the hypothesis that the higher a patient's age, the lower the chances of therapy success, whereas the patient's sex does not affect therapy results. The primary study endpoint was defined as the need for arthroplasty due to radiological evidence of collapse of the femoral head. The secondary endpoint was set as the evidence of age- or sex-dependent differences in joint

Table 1 Study collective's baseline characteristics relating to the total number of hips affected by ONFH

\begin{tabular}{ll}
\hline Study collective-ONFH-hips total & $N=86$ \\
\hline ONFH-occurrence (count), monolateral/bilateral & $56 / 15$ \\
Sex (count), male/female & $66 / 20$ \\
Age (years), mean \pm SD/min./max. & $46.8 \pm 12.2 / 21.8 / 69.7$ \\
Treatment type (count), ACD/mACD & $46 / 40$ \\
Follow-up (months), mean \pm SD & $32.5 \pm 24.8$ \\
\hline
\end{tabular}

SD standard deviation 
Table 2 Baseline characteristics of the formed age- and sex-dependent ONFH-subgroups

\begin{tabular}{|c|c|c|c|c|c|}
\hline Subgroup "Age" & $\begin{array}{l}\text { ONFH, mono-/bilateral } \\
\text { (count) }\end{array}$ & $\begin{array}{l}\text { Sex, male/female } \\
\text { (count) }\end{array}$ & $\begin{array}{l}\text { Age, years (mean } \pm \\
\text { SD) }\end{array}$ & $\begin{array}{l}\text { Treatment, ACD/mACD } \\
\text { (count) }\end{array}$ & $\begin{array}{l}\text { Follow-up, months (mean } \\
\pm \text { SD) }\end{array}$ \\
\hline$<\mathbf{3 0}$ years $(N=9)$ & $8 / 1$ & $6 / 3$ & n.a. & $5 / 4$ & $33.41 \pm 24.61$ \\
\hline $\begin{array}{l}\geq \mathbf{3 0} /<\mathbf{4 0} \text { years }(N \\
=16)\end{array}$ & $11 / 5$ & $10 / 6$ & n.a. & $7 / 9$ & $39.18 \pm 26.26$ \\
\hline $\begin{array}{l}\geq \mathbf{4 0} /<50 \text { years }(N \\
=27)\end{array}$ & $23 / 4$ & $25 / 2$ & n.a. & $15 / 12$ & $34.49 \pm 24.11$ \\
\hline$\geq \mathbf{5 0}$ years $(N=34)$ & $29 / 5$ & $25 / 9$ & n.a. & $19 / 15$ & $27.44 \pm 24.90$ \\
\hline \multicolumn{6}{|l|}{ Subgroup "Sex" } \\
\hline Male $(N=66)$ & $52 / 14$ & n.a. & $47.34 \pm 11.74$ & $33 / 33$ & $29.67 \pm 23.15$ \\
\hline Female $(N=20)$ & $19 / 1$ & n.a. & $45.16 \pm 13.65$ & $13 / 7$ & $41.68 \pm 28.49$ \\
\hline
\end{tabular}

$S D$ standard deviation

function or pain level by analysing the postoperative mHHS and NRS scores.

As it is known that the treatment outcome of ONFH depends on several co-factors, the subgroups were further analysed regarding the presence and distribution of possible confounders. The parameters recorded in this context include the size of the necrotic lesion (A-C according the ARCO and Steinberg classifications), the presence of risk factors (immunosuppressive therapy, high-dose corticosteroid treatment, abuse of alcohol and nicotine and coagulation disorders) and radiological evidence of cam-type deformity of the affected hip using the alpha angle according to Nötzli [21, 22, 28, 29].

Statistical analysis was performed using SPSS $^{\circ}$ Statistics (Version 21.0, IBM ${ }^{\circ}$ ). Concerning the primary study endpoint, a Kaplan-Meier survival analysis was performed separately for the parameters "age" and "sex". The log-rank test was used to examine significant statistical differences. Significance level was set at $p<0.05$ (significant). For comparison of pre- and postoperative mHHS and NRS (secondary study endpoint) sample distribution was tested using the Kolmogorov-Smirnov test. In case of normal distribution, the $t$ test for independent and dependent parametric samples was used; otherwise, the Wilcoxon rank-sum test was utilized. Patients with treatment failure in the postoperative course were not considered. Regarding the influence of possible confounders, cross tables combined with the chi-square test were used to describe their distribution in the subgroups and thereby check for relevant differences.

\section{Results}

Primary study endpoint - treatment failure

In the study collective as a whole, collapse of the femoral head and thereby failure of treatment was identified in 32 hips (37.2\%) during the follow-up period. As regards the patients' sex, treatment failed in 26 out of 66 male hips $(39.4 \%)$ after an average of 11.15 ( \pm 8.87) months. For the female participants, treatment failure was registered in 6 out of 20 hips (30\%) after an average 6.33 ( \pm 3.68) months (Table 3). Using the Kaplan-Meier survival estimator, a mean survival time of 51.3 months was calculated for the male hips, while the mean survival of the female hips was 61.4 months. However, despite the better survival of the female hips, the differences were not statistically significant in the log-rank test $(p=0.48)$ (Fig. 1).

Regarding the parameter "age", therapy failure was documented in 2 cases $(22.22 \%)$ in subgroup $1(<30$ years) after an average of $4.00( \pm 4.24)$ months. Subgroup $2(\geq 30 /<40$ years) also had 2 cases $(12.50 \%, 5.50$ months \pm 0.71$)$ of treatment failure, whereas subgroups

Table 3 Age- and sex-dependent therapy outcome in total numbers and rounded percentages

\begin{tabular}{|c|c|c|c|c|}
\hline \multirow[t]{2}{*}{ Study collective } & & \multicolumn{3}{|c|}{ Therapy failure (count and percentage) } \\
\hline & & $\overline{\mathrm{No}}$ & Yes & Subgroup total \\
\hline Subgroup 1 (<30 years) & Total male/female & $\begin{array}{l}7 \text { (77.78\%) } \\
5 / 2(55.56 \% / 22.22 \%)\end{array}$ & $\begin{array}{l}2 \text { (22.22\%) } \\
1 / 1(11.11 \% / 11.11 \%)\end{array}$ & $\begin{array}{l}9 \text { (100\%) } \\
6 / 3(66.67 \% / 33.33 \%)\end{array}$ \\
\hline Subgroup 2 ( $\geq 30 /<40$ years) & Total male/female & $\begin{array}{l}14(87.50 \%) \\
9 / 5(56.25 \% / 31.25 \%)\end{array}$ & $\begin{array}{l}2 \text { (12.50\%) } \\
1 / 1(6.25 \% / 6.25 \%)\end{array}$ & $\begin{array}{l}16(100 \%) \\
10 / 6(62.50 \% / 37.50 \%)\end{array}$ \\
\hline Subgroup 3 ( $\geq 40 /<50$ years) & Total male/female & $\begin{array}{l}16 \text { (59.26\%) } \\
14 / 2(51.85 \% / 7.41 \%)\end{array}$ & $\begin{array}{l}11(40.74 \%) \\
11 / 0(40.75 \% / 0 \%)\end{array}$ & $\begin{array}{l}27 \text { (100\%) } \\
25 / 2(92.59 \% / 7.41 \%)\end{array}$ \\
\hline Subgroup 4 ( $\geq 50$ years) & Total male/female & $\begin{array}{l}17(\mathbf{5 0 . 0 0 \% )} \\
12 / 5(35.29 \% / 14.71 \%)\end{array}$ & $\begin{array}{l}17(\mathbf{5 0 . 0 0 \% )} \\
13 / 4(38.24 \% / 11.76 \%)\end{array}$ & $\begin{array}{l}34 \text { (100\%) } \\
25 / 9(73.53 \% / 26.47 \%)\end{array}$ \\
\hline Total & & 54 (62.79\%) & 32 (37.21\%) & 86 (100\%) \\
\hline
\end{tabular}




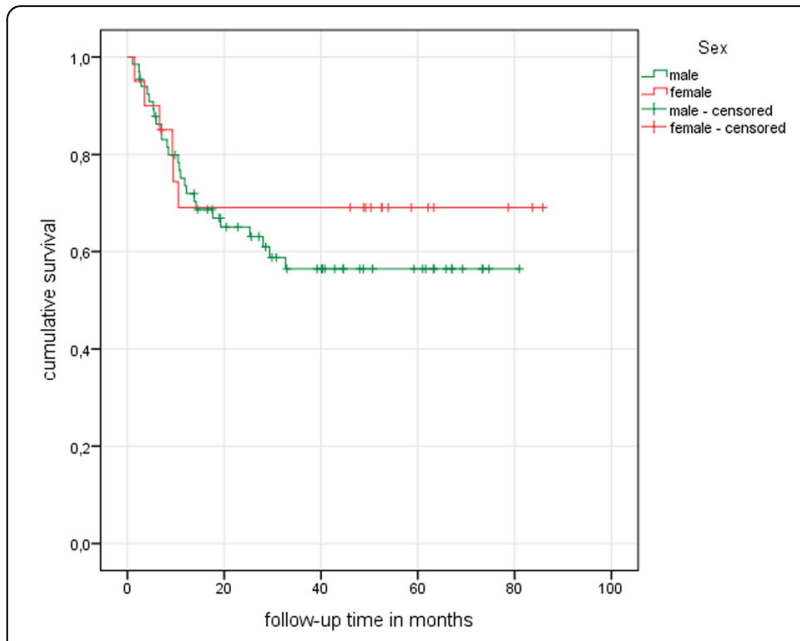

Fig. 1 Kaplan-Meier curve showing sex-dependent hip survival

$3(\geq 40 /<50$ years) and 4 ( $\geq 50$ years) presented with 11 $(40.47 \%, 14.91$ months \pm 11.47$)$ and 17 (50\%, 8.53 months \pm 5.00 ) unsatisfactory therapy results respectively (Table 3). As the differences in hip survival between subgroups 1 and 2, as well as between subgroups 3 and 4 were not significant during the observation period; a cut-off was made at the age of 40. By means of KaplanMeier survival analysis, a mean hip survival of 66.09 months was calculated for study participants younger than 40 years of age. Study subjects older than 40 showed a calculated mean survival of 50.14 months. The log-rank test showed these differences to be significant with $p=0.03$ (Fig. 2).

\section{Secondary study endpoint-clinical outcome}

Evaluation of the preoperative mHHS and NRS data revealed an overall preoperative mean mHHS of $69.93( \pm$ $13.81)$ and a mean NRS of 3.79 ( \pm 2.14). Overall

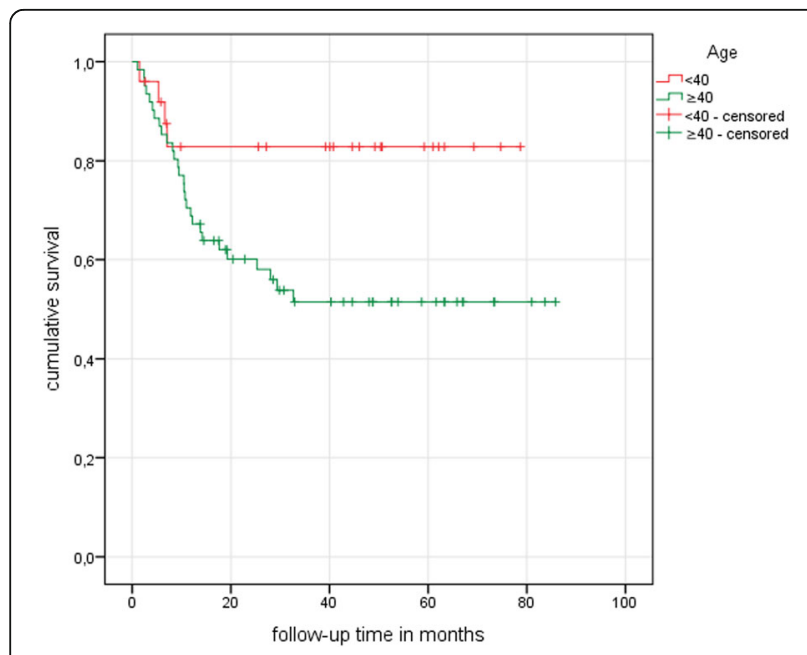

Fig. 2 Kaplan-Meier curve showing age-dependent hip survival postoperative results showed a significant improvement with the mean final mHHS at $86.13( \pm 7.99)$ and mean final NRS at $0.96( \pm 1.52)$ at the final postoperative assessment $(p<0.001$ each).

Concerning the sex-based subgroups, the mHHS of the male participants improved from $71.39( \pm 13.92)$ to $86.70( \pm 7.82)$ and the NRS from $3.59( \pm 2.22)$ to $0.75( \pm$ $1.13)$ over the study period. For the female study patients, an improvement in the mHHS from 65.10 ( \pm $12.60)$ to $84.50( \pm 8.55)$, and in the NRS from 4.45 ( \pm $1.73)$ to $1.57( \pm 2.24)$ was seen. Both subgroups showed a similar increase in the mean mHHS (15.31 vs. 19.40) and a similar decrease in the mean NRS (2.84 vs. 2.88) during follow-up with inter-subgroup differences not being significant $(p>0.05)$. Similar changes were also to be seen at the corresponding follow-up times (Table 4). It must be mentioned that despite a similar overall improvement, the female participants had a distinctly higher pre- and postoperative NRS score in comparison to their male counterparts.

As for the parameter "sex", the alterations in mHHS and NRS were analogical in the determined age-dependent subgroups. All subgroups ( 1 ( $<30$ years), 2 ( $\geq 30 /<40$ years), 3 ( $\geq 40 /<50$ years) and 4 ( $\geq 50$ years)) showed a similar increase in mHHS, accompanied by a corresponding decrease in NRS postoperatively. These changes proved to be consistent in all subgroups during the whole follow-up period. Statistical differences appeared to be minimal and not significant (Table 4, Fig. 3). Patients with therapy failure during the follow-up period were excluded from the calculations.

\section{Possible confounders}

As the results concerning the primary endpoint indicated an age-related hip survival after treatment by means of core decompression, the distribution of possible confounders is provided for all age-dependent subgroups. The recorded parameters "lesion size", "cam-type deformity" (on the basis of the alpha angle), "risk factors" and "treatment method" showed a homogenous distribution among the subgroups. This was confirmed in the corresponding statistical evaluation using the chi-square test with each $p$ being far from significance (Table 5).

\section{Discussion}

Previous studies have shown the effect of certain parameters on the long-term outcome of ONFH therapy. These known parameters include lesion stage and lesion size as well as the presence of risk factors and concomitant hip pathologies [3, 21, 22].

As regards the parameter "age", results show distinct differences for postoperative hip survival. Whereas the age-based subgroups " $<30$ years" and " $\geq 30$ years $/<40$ years" presented a combined overall hip survival of $84 \%$, 
Table 4 Pre- and (final) postoperative age- and sex-dependent changes in mHHS and NRS

\begin{tabular}{|c|c|c|c|c|}
\hline \multirow[t]{2}{*}{ Subgroup "Age" } & \multicolumn{2}{|c|}{ mHHS (mean \pm SD) } & \multicolumn{2}{|c|}{ NRS (mean \pm SD) } \\
\hline & preoperative & postoperative & preoperative & postoperative \\
\hline $\begin{array}{l}\text { Subgroup } 1 \\
\text { (<30years) }\end{array}$ & $69.67 \pm 13.39$ & $\begin{array}{l}84.86 \pm 8.01 \\
\text { FU1 } 88.25 \pm 1.89 \\
\text { FU2 } 89.25 \pm 1.26 \\
\text { FU3 } 87.40 \pm 1.67 \\
\text { FU4 } 83.50 \pm 8.57\end{array}$ & $3.56 \pm 2.13$ & $\begin{array}{l}1.00 \pm 1.16 \\
\text { FU1 } 0.75 \pm 0.96 \\
\text { FU2 } 0.50 \pm 0.58 \\
\text { FU3 } 0.80 \pm 0.84 \\
\text { FU4 } 1.00 \pm 1.10\end{array}$ \\
\hline $\begin{array}{l}\text { Subgroup } 2 \\
(\geq 30 /<40 \text { years) }\end{array}$ & $72.31 \pm 12.65$ & $\begin{array}{l}87.07 \pm 5.21 \\
\text { FU1 } 83.92 \pm 8.14 \\
\text { FU2 } 87.67 \pm 3.72 \\
\text { FU3 } 86.50 \pm 1.00 \\
\text { FU4 } 86.00 \pm 5.07\end{array}$ & $3.75 \pm 2.30$ & $\begin{array}{l}0.93 \pm 1.33 \\
\text { FU1 } 1.00 \pm 1.16 \\
\text { FU2 } 0.83 \pm 0.98 \\
\text { FU3 } 0.75 \pm 0.96 \\
\text { FU4 } 0.86 \pm 1.22\end{array}$ \\
\hline $\begin{array}{l}\text { Subgroup } 3 \\
(\geq 40 /<50 \text { years })\end{array}$ & $72.19 \pm 14.61$ & $\begin{array}{l}86.76 \pm 8.93 \\
\text { FU1 } 85.36 \pm 8.13 \\
\text { FU2 } 88.14 \pm 4.45 \\
\text { FU3 } 89.00 \pm 4.87 \\
\text { FU4 } 87.08 \pm 8.14\end{array}$ & $3.37 \pm 2.36$ & $\begin{array}{l}1.12 \pm 2.12 \\
\text { FU1 } 0.91 \pm 1.14 \\
\text { FU2 } 0.43 \pm 0.54 \\
\text { FU3 } 0.50 \pm 0.76 \\
\text { FU4 } 1.57 \pm 2.24\end{array}$ \\
\hline Subgroup 4 ( $\geq 50$ years) & $67.09 \pm 13.84$ & $\begin{array}{l}85.19 \pm 9.40 \\
\text { FU1 } 88.00 \pm 4.99 \\
\text { FU2 } 84.00 \pm 8.76 \\
\text { FU3 } 87.56 \pm 4.50 \\
\text { FU4 } 87.10 \pm 5.13\end{array}$ & $4.21 \pm 1.89$ & $\begin{array}{l}0.81 \pm 1.11 \\
\text { FU1 } 0.43 \pm 0.65 \\
\text { FU2 } 0.90 \pm 0.99 \\
\text { FU3 } 0.56 \pm 0.73 \\
\text { FU4 } 0.70 \pm 1.06\end{array}$ \\
\hline \multicolumn{5}{|l|}{ Subgroup "Sex" } \\
\hline Male & $71.39 \pm 13.92$ & $\begin{array}{l}86.70 \pm 7.82 \\
\text { FU1 } 86.45 \pm 6.39 \\
\text { FU2 } 86.37 \pm 6.74 \\
\text { FU3 } 87.71 \pm 4.08 \\
\text { FU4 } 86.22 \pm 6.35\end{array}$ & $3.59 \pm 2.22$ & $\begin{array}{l}0.75 \pm 1.13 \\
\text { FU1 } 0.83 \pm 1.10 \\
\text { FU2 } 0.74 \pm 0.81 \\
\text { FU3 } 0.57 \pm 0.75 \\
\text { FU4 } 1.07 \pm 1.51\end{array}$ \\
\hline Female & $65.10 \pm 12.60$ & $\begin{array}{l}84.50 \pm 8.55 \\
\text { FU1 } 85.23 \pm 8.01 \\
\text { FU2 } 87.38 \pm 5.07 \\
\text { FU3 } 88.20 \pm 2.68 \\
\text { FU4 } 86.38 \pm 8.47\end{array}$ & $4.45 \pm 1.73$ & $\begin{array}{l}1.57 \pm 2.24 \\
\text { FU1 } 0.62 \pm 0.65 \\
\text { FU2 } 0.63 \pm 0.92 \\
\text { FU3 } 0.80 \pm 0.84 \\
\text { FU4 } 1.11 \pm 1.63\end{array}$ \\
\hline Total & $69.93 \pm 13.81$ & $86.13 \pm 7.99$ & $3.79 \pm 2.14$ & $0.96 \pm 1.52$ \\
\hline
\end{tabular}

SD standard deviation, FU1 follow-up 6 weeks, FU2 follow-up 6 months, FU3 follow-up 12 months, FU4 follow-up 24 months

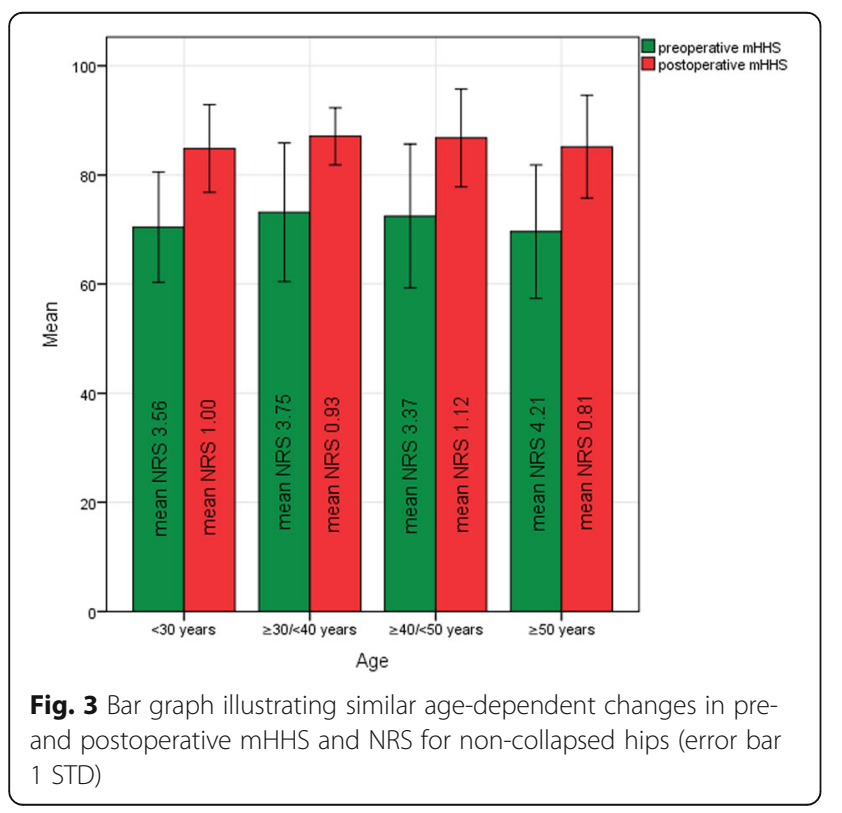

older patients aged " $\geq 40$ years $/<50$ years" and " $>50$ years" had a significantly lower rate of only $54 \%$ of the combined hip survival over the study period. There is therefore a strong indication that at around the age of forty, there is a turning point in the long-term results of ONFH therapy.

It is known that bone healing in general and regeneration after ONFH strongly depends on the capacity of the individual's body to repair and remodel the affected bone [30]. Although the underlying biochemical processes are not yet fully understood, a two-phase model consisting of a disintegrating osteoclast-driven phase and a bone-rebuilding osteoblast-driven phase is assumed [31]. Both phases are controlled by numerous growth and signal factors which balance the course of bone resorption and bone formation (e.g., bone morphogenetic proteins (BMP), tumour necrosis factor (TNF) and osteoprotegerin (OPG)) [32-34]. Basically, these reparative mechanisms are intended to work throughout life. Nevertheless, with increasing age, the human organism's ability to make sufficient use of them seems to 
Table 5 Distribution of possible confounders among age-related subgroups in total numbers and rounded percentages

\begin{tabular}{|c|c|c|c|c|c|}
\hline \multirow[t]{2}{*}{ Possible confounder } & & \multicolumn{4}{|c|}{ Age-related ubgroups (count and percentage) } \\
\hline & & $<30$ years & $\geq 30 /<40$ years & $\geq 40 /<50$ years & $\geq 50$ years \\
\hline \multirow[t]{5}{*}{ Lesion Size } & $<15 \%$ & $1(11.1 \%)$ & $2(12.5 \%)$ & $2(7.4 \%)$ & $2(5.9 \%)$ \\
\hline & $\geq 15 / \leq 30 \%$ & $4(44.4 \%)$ & $8(50 \%)$ & $15(55.6 \%)$ & $22(64.7 \%)$ \\
\hline & $>30 \%$ & $4(44.4 \%)$ & $6(37.5 \%)$ & $10(37.0 \%)$ & $10(29.4 \%)$ \\
\hline & Total & $9(100 \%)$ & $16(100 \%)$ & $27(100 \%)$ & $34(100 \%)$ \\
\hline & & $p=0.92$ & & & \\
\hline \multirow[t]{5}{*}{ Alpha angle } & $<50^{\circ}$ & $2(22.2 \%)$ & $3(18.8 \%)$ & 7 (25.9\%) & $8(23.5 \%)$ \\
\hline & $\geq 50^{\circ} /<60^{\circ}$ & $3(33.3 \%)$ & $5(31.3 \%)$ & $7(25.9 \%)$ & $10(29.4 \%)$ \\
\hline & $\geq 60^{\circ}$ & $4(44.4 \%)$ & $8(50.0 \%)$ & $13(48.1 \%)$ & $16(47.1 \%)$ \\
\hline & Total & $9(100 \%)$ & $16(100 \%)$ & $27(100 \%)$ & $34(100 \%)$ \\
\hline & & $p=0.99$ & & & \\
\hline \multirow[t]{4}{*}{ Risk factor } & No & $4(44.4 \%)$ & $8(50.0 \%)$ & $11(40.7 \%)$ & 19 (55.9\%) \\
\hline & Yes & $5(55.6 \%)$ & 8 (50.0\%) & $16(59.3 \%)$ & $15(44.1 \%)$ \\
\hline & Total & 9 (100\%) & $18(100 \%)$ & 27 (100\%) & $34(100 \%)$ \\
\hline & & $p=0.69$ & & & \\
\hline \multirow[t]{4}{*}{ Treatment type } & $A C D$ & $5(55.6 \%)$ & 7 (43.75\%) & 15 (55.6\%) & 19 (55.9\%) \\
\hline & mACD & $4(44.4 \%)$ & 9 (56.25\%) & $12(44.4 \%)$ & $15(44.1 \%)$ \\
\hline & Total & 9 (100\%) & $16(100 \%)$ & 27 (100\%) & 34 (100\%) \\
\hline & & $p=0.86$ & & & \\
\hline
\end{tabular}

diminish. Recent studies have shown that fracture healing in elderly patients appears to take place rather slowly or with insufficient stability due to reduced mineral density [35-38]. It has also been shown that in vitro differentiation of bone marrow stroma cells to osteoblasts is less successful in cultures from older patients in comparison to those from younger patients [39].. Insufficiency of tissue regeneration in ONFH becomes even more apparent with regard to fibrosis. In this context, Sadile et al. evaluated the extension of histological fibrosis in a series of specimens from ONFH-biopsies. By proving a negative correlation, they were able to show that the extension of reactive fibrosis is a predictor of outcome of core decompression [40].

Regarding angioneogenesis, an important aspect in the healing process of ONFH, a decrease in regenerative potential can also be seen. As pluripotent bone marrow stroma cells decrease in number and potential for differentiation, the organism's capacity to revascularize necrotic zones is highly limited. This condition is further aggravated by the aging of existing vessels, known as vascular aging, which is characterized by a progressive endothelial cell and smooth muscle cell dysfunction [41, 42].

Overall, it is known that the aging organism presents an increasing loss of functional tissue cells leading to an ongoing reduction in the ability of the tissues to maintain and replace themselves [43]. Therefore, it is not surprising that the success of ONHF therapy decreases with increasing age, and this is reflected in the rate of postoperative hip survival. The age of forty seems to mark a limit, with patients aged under forty having a significantly better chance of long-term hip survival after ACD, whereas about half of the patients older than 40 have to face therapy failure in the postoperative course. However, in this context, it must be noted that the short-term postoperative course seems to be similar in all patients, irrespective of age. As shown in Fig. 3, the Kaplan-Meier curves appear to be identical for the age groups $<40$ and $\geq 40$ years of age until the sixth month of the follow-up period (Fig. 2 ). Therefore, age-related factors affecting the overall therapy outcome seem to gain in importance only in the further postoperative course.

Concerning the parameter "sex", it is known that the occurrence of ONFH is distributed unevenly between the sexes, affecting predominantly men $[5,6]$. However, apart from its uneven distribution which might be due to still unknown sex-based factors according to Shimizu et al., sex as a parameter influencing the long-term outcome of ONFH-therapy had not previously been evaluated [23]. The present study indicates that patients' sex seems to have no influence on therapy as the results of the calculated Kaplan-Meier estimator could not prove any significant sex-dependent differences in hip survival $(p=0.48)$. Therefore, it can be assumed that, based on current knowledge, the parameter "sex" is not relevant for the prediction of long-term ONFH therapy outcome. 
However, as calculations revealed some differences in mean hip survival (male 51.3 months vs. female 61.4 months), the uneven distribution of the number of male and female study participants has to be taken into account. With only 20 female study patients, out of a total study collective of 86 , statistical calculations might be biased and further examination with a greater number of female participants is required to confirm the study results. In this context, this study's finding which indicates an earlier occurrence of treatment failure in the female subpopulation has to be verified as well.

As far as functional parameters and changes in pain levels are concerned, the study results appeared very uniform. A distinct amelioration of function of the affected hip, proved through a significant increase in $\mathrm{mHHS}$ from pre- to postoperative, was seen. A significant decrease in NRS demonstrated a clear improvement of postoperative pain levels. These findings were seen in the patients whose therapy was still successful after the follow-up period and were nearly identical, irrespective of the patient's sex or age. Furthermore, this study's results show consistent subgroup changes in mHHS and NRS at the different followup times. It follows that, in case of non-appearance of treatment failure, the process of rehabilitation is not affected by the parameters sex and age.

The results of the given study are limited by the fact that patient numbers of the investigated age groups were not evenly distributed. Therefore, an effect on the statistical analysis cannot be excluded. By proving a homogenous distribution of the possible confounders "lesion size", "alpha angle", "risk factors" and "surgery type" within the subgroups, an unwanted effect on the overall results was attempted to eliminate (Table 3). However, as there are further possible confounders which could not be taken into account in the analysis (e.g. body mass index), a bias cannot be completely excluded [44]. Furthermore, it must be taken into account that the results presented in this study, although focused on the parameters "age" and "sex", are based on the therapeutic intervention of core decompression. Although core decompression and its modifications are still widely used, its overall status in the treatment of ONFH has been repeatedly criticized. In their meta-analysis from 2016, Sadile et.al. were able to prove that especially classic core decompression does not improve clinical outcomes compared with other jointpreserving therapies. There even is some indication for less beneficial overall results [45]. On the whole, determining the role of core decompression remains difficult since lots of modifications have been described so far, and there is a lack of comparing studies. Hence, comparative analyses of the different surgical and non-surgical techniques regarding age- and sex-related outcome need to be undertaken in the future to further substantiate this study's findings.

\section{Conclusion}

The current study shows a distinct age-dependent rate of hip survival of ONFH patients treated by advanced core decompression. Therapy failure is significantly more likely to be seen in patients over 40 years of age. Patients' sex does not seem to affect treatment outcome. For the patients who did not experience therapy failure during follow-up, postoperative clinical scores were independent of the parameters age and sex, and the rehabilitation process was not affected. Since the patient's sex and age are unalterable parameters, the study cannot recommend any specific measures for the treatment of ONFH. However, it does show that therapy results are strongly age-dependent and thus it enables valuable predictions regarding the chances of long-term hip survival.

\section{Abbreviations}

ONFH: Osteonecrosis of the femoral head; mHHS: Modified Harris Hip Score; NRS: Numeric rating scale; ACD: Advanced core decompression;

mACD: Modified advanced core decompression

\section{Acknowledgements}

We acknowledge the support by the Deutsche Forschungsgemeinschaft (DFG, German Research Foundation) and Saarland University within the funding programme Open Access Publishing.

Ethical approval and consent to participate

The study was approved by the local ethics committee under the number 10-4293. Informed consent was obtained from all patients enrolled in this study

\section{Authors' contributions}

SS collected data and wrote the manuscript. $\mathrm{MH}, \Pi$ and FD performed statistical analysis and contributed in manuscript preparation. SL contributed in designing the study and revising the manuscript. The authors read and approved the final manuscript.

\section{Funding}

There is no funding source.

\section{Availability of data and materials}

The data that supports the findings of this study are available from the corresponding author upon reasonable request.

Consent for publication

All authors have approved the manuscript for publication.

\section{Competing interests}

There are no conflicts (financial and non-financial) to be declared.

\section{Author details}

${ }^{1}$ Department of Orthopaedics \& Orthopaedic Surgery, Saarland University, Kirrberger Strasse 100, 66421 Homburg, Germany. ${ }^{2}$ Department of

Orthopaedics \& Traumatology, University of Duisburg-Essen, Essen, Germany.

Received: 21 January 2020 Accepted: 20 March 2020

Published online: 31 March 2020

\section{References}

1. Mont MA, Hungerford DS. Non-traumatic avascular necrosis of the femoral head. J Bone Joint Surg Am. 1995;77:459-74.

2. Mankin HJ. Nontraumatic necrosis of bone (osteonecrosis). N Engl J Med. 1992;326:1473-9. https://doi.org/10.1056/NEJM199205283262206.

3. Mont MA, Cherian JJ, Sierra RJ, Jones LC, Lieberman JR. Nontraumatic osteonecrosis of the femoral head: where do we stand today? A ten-year update. J Bone Joint Surg Am. 2015;97:1604-27. https://doi.org/10.2106/ JBJS.0.00071. 
4. Seamon J, Keller T, Saleh J, Cui Q. The pathogenesis of nontraumatic osteonecrosis. Arthritis. 2012;2012:601763. https://doi.org/10.1155/2012/ 601763

5. Kang JS, Park S, Song JH, Jung YY, Cho MR, Rhyu KH. Prevalence of osteonecrosis of the femoral head: A nationwide epidemiologic analysis in Korea. J Arthroplasty. 2009:24:1178-83. https://doi.org/10.1016/..arth.2009.05.022.

6. Fukushima W, Fujioka M, Kubo T, Tamakoshi A, Nagai M, Hirota Y. Nationwide epidemiologic survey of idiopathic osteonecrosis of the femoral head. Clin Orthop Relat Res. 2010;468:2715-24. https://doi.org/10.1007/s11999-010-1292-X.

7. Camporesi E, Vezzani G, Zanon V, Manelli D, Enten G, Quartesan S, Bosco G. Review on hyperbaric oxygen treatment in femoral head necrosis. Undersea Hyperb Med. 2017:44:497-508.

8. Nakamura J, Harada Y, Oinuma K, lida S, Kishida S, Takahashi K. Spontaneous repair of asymptomatic osteonecrosis associated with corticosteroid therapy in systemic lupus erythematosus: 10-year minimum follow-up with MRI. Lupus. 2010;19:1307-14. https://doi.org/10.1177/0961203310372951.

9. Lee Y-K, Ha Y-C, Cho YJ, Suh KT, Kim S-Y, Won Y-Y, et al. Does zoledronate prevent femoral head collapse from osteonecrosis? A prospective, randomized, open-label, multicenter study. J Bone Joint Surg Am. 2015;97: 1142-8. https://doi.org/10.2106/JBJS.N.01157.

10. Disch AC, Matziolis G, Perka C. The management of necrosis-associated and idiopathic bone-marrow oedema of the proximal femur by intravenous iloprost. J Bone Joint Surg Br. 2005;87:560-4. https://doi.org/10.1302/0301620X.87B4.15658.

11. Glueck CJ, Freiberg RA, Sieve L, Wang P. Enoxaparin prevents progression of stages I and II osteonecrosis of the hip. Clin Orthop Relat Res. 2005:164-70. https://doi.org/10.1097/01.blo.0000157539.67567.03.

12. Lai K-A, Shen W-J, Yang C-Y, Shao C-J, Hsu J-T, Lin R-M. The use of alendronate to prevent early collapse of the femoral head in patients with nontraumatic osteonecrosis. A randomized clinical study. J Bone Joint Surg Am. 2005;87:2155-9. https://doi.org/10.2106/JBJS.D.02959.

13. Vulpiani MC, Vetrano M, Trischitta D, Scarcello L, Chizzi F, Argento G, et al. Extracorporeal shock wave therapy in early osteonecrosis of the femoral head: prospective clinical study with long-term follow-up. Arch Orthop Trauma Surg. 2012;132:499-508. https://doi.org/10.1007/s00402-011-1444-9.

14. Xie K, Mao Y, Qu X, Dai K, Jia Q, Zhu Z, Yan M. High-energy extracorporeal shock wave therapy for nontraumatic osteonecrosis of the femoral head. $J$ Orthop Surg Res. 2018;13:25. https://doi.org/10.1186/s13018-017-0705-X.

15. Wang C-J, Huang C-C, Wang J-W, Wong T, Yang Y-J. Long-term results of extracorporeal shockwave therapy and core decompression in osteonecrosis of the femoral head with eight- to nine-year follow-up. Biomed J. 2012;35:481-5. https://doi.org/10.4103/2319-4170.104413.

16. Lieberman JR, Conduah A, Urist MR. Treatment of osteonecrosis of the femoral head with core decompression and human bone morphogenetic protein. Clin Orthop Relat Res. 2004:139-45.

17. Landgraeber S, Theysohn JM, Classen T, Jäger M, Warwas S, Hohn H-P, Kowalczyk W. Advanced core decompression, a new treatment option of avascular necrosis of the femoral head--a first follow-up. J Tissue Eng Regen Med. 2013;7:893-900. https://doi.org/10.1002/term.1481.

18. Liu D, Chen Q, Chen Y, Liu Y. Long-term follow-up of early-middle stage avascular necrosis of femoral head with core decompression and bone grafting. Zhongguo Xiu Fu Chong Jian Wai Ke Za Zhi. 2012;26:1165-8.

19. Rajagopal M, Balch Samora J, Ellis TJ. Efficacy of core decompression as treatment for osteonecrosis of the hip: a systematic review. Hip Int. 2012;22: 489-93. https://doi.org/10.5301/HIP.2012.9748.

20. Steinberg ME, Hayken GD, Steinberg DR. A quantitative system for staging avascular necrosis. J Bone Joint Surg Br. 1995;77:34-41.

21. Classen $T$, Warwas $S$, Jäger M, Landgraeber $S$. Two-year follow-up after advanced core decompression. J Tissue Eng Regen Med. 2017;11:1308-14. https://doi.org/10.1002/term.2056.

22. Serong S, Haversath $M$, Jäger $M$, Landgraeber S. Prevalence of CAM deformity and its influence on therapy success in patients with osteonecrosis of the femoral head. J Tissue Eng Regen Med. 2019. https:// doi.org/10.1002/term.2794.

23. Shimizu J, Okazaki S, Nagoya S, Takahashi N, Kanaya K, Mizuo K, et al. Susceptibility of males, but not females to developing femoral head osteonecrosis in response to alcohol consumption. PLoS One. 2016;11: e0165490. https://doi.org/10.1371/journal.pone.0165490.

24. Gardeniers JWM, Gosling-Gardeniers AC, Rijnen WHC. The ARCO staging system: generation and evolution since 1991. In: Osteonecrosis: Springer; 2014. p. 215-8.
25. Kumar P, Sen R, Aggarwal S, Agarwal S, Rajnish RK. Reliability of modified Harris Hip Score as a tool for outcome evaluation of total hip replacements in Indian population. J Clin Orthop Trauma. 2019;10:128-30. https://doi.org/ 10.1016/j.jcot.2017.11.019.

26. Williamson A, Hoggart B. Pain: a review of three commonly used pain rating scales. J Clin Nurs. 2005;14:798-804. https:/doi.org/10.1111/j.1365-2702.2005.01121x.

27. Landgraeber S, Warwas S, Claßen T, Jäger M. Modifications to advanced core decompression for treatment of avascular necrosis of the femoral head. BMC Musculoskelet Disord. 2017;18:479. https://doi.org/10.1186/ s12891-017-1811-y.

28. Drescher W, Pufe T, Smeets R, Eisenhart-Rothe RV, Jäger M, Tingart M Hüftkopfnekrose - Diagnostik und Differenzialtherapie. Z Orthop Unfall. 2011;149:231-40; quiz 241-2. https://doi.org/10.1055/s-0030-1270984.

29. Nötzli HP, Wyss TF, Stoecklin CH, Schmid MR, Treiber K, Hodler J. The contour of the femoral head-neck junction as a predictor for the risk of anterior impingement. J Bone Joint Surg Br. 2002;84:556-60.

30. Tingart M, Beckmann J, Opolka A, Matsuura M, Wiech O, Grifka J, Grässel S. Influence of factors regulating bone formation and remodeling on bone quality in osteonecrosis of the femoral head. Calcified Tissue International. 2008;82:300-8. https://doi.org/10.1007/s00223-008-9111-z.

31. Karsenty G. How many factors are required to remodel bone? Nat Med. 2000;6:970-1. https://doi.org/10.1038/79655.

32. Li X, Cao X. BMP signaling and skeletogenesis. Ann N Y Acad Sci. 2006;1068 26-40. https://doi.org/10.1196/annals.1346.006.

33. Durnez A, Paternotte S, Fechtenbaum J, Landewé RBM, Dougados M, Roux C, Briot K. Increase in bone density in patients with spondyloarthritis during anti-tumor necrosis factor therapy: 6-year followup study. J Rheumatol. 2013:40:1712-8

34. Lacey DL, Timms E, Tan HL, Kelley MJ, Dunstan CR, Burgess T, et al. Osteoprotegerin ligand is a cytokine that regulates osteoclast differentiation and activation. Cell. 1998:93:165-76.

35. Hak DJ, Fitzpatrick D, Bishop JA, Marsh JL, Tilp S, Schnettler R, et al. Delayed union and nonunions: epidemiology, clinical issues, and financial aspects. Injury. 2014;45(Suppl 2):S3-7. https://doi.org/10.1016/j.injury.2014.04.002.

36. Nandra R, Grover L, Porter K. Fracture non-union epidemiology and treatment. Trauma. 2016;18:3-11.

37. Robinson CM, Royds M, Abraham A, McQueen MM, Court-Brown CM, Christie J. Refractures in patients at least forty-five years old. a prospective analysis of twenty-two thousand and sixty patients. J Bone Joint Surg Am. 2002;84-A:1528-33.

38. Gruber R, Koch H, Doll BA, Tegtmeier F, Einhorn TA, Hollinger JO. Fracture healing in the elderly patient. Exp Gerontol. 2006;41:1080-93. https://doi. org/10.1016/j.exger.2006.09.008.

39. D'Ippolito G, Schiller PC, Ricordi C, Roos BA, Howard GA. Age-related osteogenic potential of mesenchymal stromal stem cells from human vertebral bone marrow. J Bone Miner Res. 1999;14:1115-22. https://doi.org/ 10.1359/jbmr.1999.14.7.1115

40. Sadile F, Bernasconi A, Carbone F, Lintz F, Mansueto G. Histological fibrosis may predict the failure of core decompression in the treatment of osteonecrosis of the femoral head. Int J Surg. 2017:44:303-8. https://doi.org/ 10.1016/j.jijsu.2017.06.079

41. Matthews C, Gorenne I, Scott S, Figg N, Kirkpatrick P, Ritchie A, et al. Vascular smooth muscle cells undergo telomere-based senescence in human atherosclerosis: effects of telomerase and oxidative stress. Circ Res. 2006;99:156-64

42. Mistriotis $P$, Andreadis ST. Vascular aging: molecular mechanisms and potential treatments for vascular rejuvenation. Ageing Res Rev. 2017;37:94116. https://doi.org/10.1016/j.arr.2017.05.006

43. Carrington JL. Aging bone and cartilage: cross-cutting issues. Biochem Biophys Res Commun. 2005;328:700-8. https://doi.org/10.1016/j.bbrc.2004.12.041.

44. Ha Y-C, Kim HJ, Kim S-Y, Kim K-C, Lee Y-K, Koo K-H. Effects of age and body mass index on the results of transtrochanteric rotational osteotomy for femoral head osteonecrosis. J Bone Joint Surg Am. 2010;92:314-21. https:// doi.org/10.2106/JBJS.H.01020.

45. Sadile F, Bernasconi A, Russo S, Maffulli N. Core decompression versus other joint preserving treatments for osteonecrosis of the femoral head: a metaanalysis. Br Med Bull. 2016;118:33-49. https://doi.org/10.1093/bmb/ldw010.

\section{Publisher's Note}

Springer Nature remains neutral with regard to jurisdictional claims in published maps and institutional affiliations. 